\title{
The College Access Debate: Class Considerations And College Preparation
}

Matthew R. Hodgman, West Virginia University, USA

\begin{abstract}
The college access debate in America remains an important one. Affirmative action policies and practices continue to occupy a significant sub-component of the overall college access discussion. Recent legal debates and policy changes pertaining to affirmative action have encouraged analysis surrounding the overall viability and fairness of these policies. This article describes the current parameters and arguments surrounding the college access debate in America in relation to affirmative action practices and makes suggestions as to how these practices can be improved. Three major aims of the article are to articulate the shortcomings of affirmative action practices in their current forms, to investigate the potential benefits of considering students' social-class backgrounds when making affirmative action admissions decisions at institutions of higher education, and to ultimately point out that college access factors prior to and following the admissions process, such as college preparation and the degree of support mechanisms in place after matriculation, are potentially more important to the access debate than affirmative action considerations. This article concludes that all students can significantly benefit from exposure to higher education and that affirmative action policies should address social class in some capacity or be abandoned.
\end{abstract}

Keywords: College Access; Affirmative Action; Social Class; College Preparation

\section{INTRODUCTION}

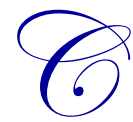

ollege access has increasingly become a central issue in higher education. Affirmative action continues to be an important sub-component of the overall access debate. Recently, the state of New Hampshire decided to end affirmative action (AA) preferences at their public colleges and universities. Supporters of this measure argued that AA sets the intended beneficiaries up for failure and causes others to question how much these beneficiaries have actually accomplished (Schmidt, 2012). Opponents of the action claimed that ending preferences would disadvantage underrepresented populations and that AA improves the learning environment by exposing all students and employees to a broader range of perspectives on important issues. The action in New Hampshire begs the following questions: 1) Are calls to ban AA in-effect votes against the future intellectual capital of our country? 2) Is AA imperative to a democratic society? 3) Are higher education academic excellence and social equity mutually exclusive?

Colleges should be weary of employing AA methods in their current form and under the guise of current legal reasoning. After Grutter v. Bollinger (2003) AA supposedly can provide educational benefits for all students by exposing them to a diverse student body. However, how are we defining "diverse" here? It does not appear that current AA mandates for colleges and universities are truly conducive to optimal diversity on college campuses. If race and gender are being considered during the college admissions process, why not consider other descriptors such as social class? Traditionally, AA has been utilized to atone for the effects of historic discrimination, but certainly those of lower socio-economic standing have and continue to be marginalized, just as racial minorities and women have been. The U.S. Supreme Court has agreed to hear arguments in fall 2012 surrounding Fisher v. University of Texas at Austin, which could eliminate affirmative action in college admissions and generally bring into question all practices of giving preferential treatment to specific social groups in admissions and hiring processes. The Fisher case will ask the court to decide if race-conscious admissions policies violate civil and constitutional rights. Fisher invites us, as a nation, to consider the pros and cons of affirmative action. It is the opinion of the author that college AA policies must consider social class in some capacity or be completely ended. 
This paper will investigate the potential benefits of considering social-class when making affirmative action admissions decisions at institutions of higher education. The question of access in higher education will be discussed generally and it will be suggested that all students can significantly benefit from exposure to higher education. Ultimately, this paper points out that college admission is only one factor in the college access debate and concludes that access factors prior to the admissions process, such as college preparedness and the degree of support mechanisms in place after matriculation are potentially more important to the access debate than admissions issues such as AA.

\section{OTHER FACTORS}

Beyond admissions, many other factors color the college access debate. The rising cost of tuition, social disadvantages, and lack of academic preparedness all contribute to the under-representation of low-income and minority students on college campuses. Cost in particular has been a major barrier to college access in recent history. As costs rose during the 1990s and early 2000s, the percentage of academically qualified low-income high school graduates attending four-year colleges fell, from 54 percent in 1992 to 40 percent in 2004, and the percentage of qualified moderate-income students dropped from 59 percent to 53 percent (Education Week, 2011). Although federal financial aid has offset the rising costs of higher education in some cases, many students still struggle to afford college. Changes in federal financial aid programs, merit-based scholarship programs, and a shift toward tuition tax credits that primarily help the middle-class have exacerbated the postsecondary participation gap (Education Week, 2011).

Perhaps the most important issue related to access is academic preparedness. Many students are simply not being prepared for the academic and social rigors of college. This reality has led some to question whether all students should attend college and how we can better prepare students for all higher educational opportunities. Should we consider students who do not go on to complete some form of higher education failures? Clearly, not all students need a college credential to be successful and college may not be right for everyone, however, there are clear benefits to college exposure that all students should be made aware of. Republican presidential hopeful Rick Santorum recently called President Obama a "snob" for suggesting that all students should go to college. Contrary to Santorum's comment, studies show that all students can benefit economically from at least some exposure to higher education. According to the College Board (2005), students with some exposure to college make on average nearly $\$ 5,000$ more annually than those who only graduate from high school and students with an associate's degree make nearly $\$ 8,000$ more than high school graduates (p. 2). In addition, exposure to higher education is also associated with increased employee benefits, voter participations rates, and overall health (College Board, 2005). In terms of future job prospects, two-thirds of the jobs created in the United States by 2018 will require some postsecondary education, but of those, nearly half will go to people with occupational certificates or associate degrees (Education Week, 2011). This means that students will likely need post-secondary academic credentials of some kind in order to be viewed as viable job candidates going forward.

Beyond economic rewards, there are intangible rewards that college exposure can provide. According to a recent Pew survey, 84 percent of those with degrees said college had been a good investment; only 7 percent said it had not (Hoover, 2011). In addition, the same Pew survey asked all respondents about the "main purpose" of college. Forty-seven percent said "to teach knowledge and skills that can be used in the workplace," 39 percent said "to help an individual grow personally and intellectually," and 12 percent said "both equally" (Hoover, 2011). This shows us that there are a wide variety subjective benefits one can accrue from a college education. Social development, networking, and general exposure to a vast sphere of influences can help students more clearly envision their future goals and develop the confidence necessary to accomplish everyday life activities.

\section{SUGGESTIONS}

Clearly all students can benefit from higher education along these indicators, but, regardless of race or class, students are not likely to be admitted to colleges or graduate if they are not prepared to succeed in postsecondary academic environments. Growing numbers of underrepresented students should be assisted with the transition from k-12 to college, but admissions committees should not admit students who are otherwise unqualified based on AA criteria. Access issues should be primarily addressed before college, not by admissions committees. 
Consider these statistics: In 2010, three out of every five community college students needed at least one remedial course, and fewer than 25 percent of those students successfully earn a degree within eight years (Education Week, 2011). These numbers attest to this disconnect between higher education institutions and the K-12 system. Early intervention programs and P-16 councils can be important tools to help underserved students access college; these students need to know more about higher education and its requirements and possess the skills necessary to succeed in college. Colleges can play a major role in providing guidance to economically underserved secondary school students in terms of college preparation. For example, the University of California System has set up an extensive outreach program in lower-income school districts that help prepare underserved students for post-secondary education. The University of California system actively helps students in elementary school on up and their family members better understand the college admissions process throughout the Cal system and provides underserved students with supports that better prepare them for college (Leonhardt, 2007). This is the type of involvement that can help students understand how to gain college admission on academic merits. Although the Cal system is doing young students a valuable service, a general lack of educational coordination across levels in the U.S. prevents students from adequately preparing for a college transition. States should step in to encourage collaboration between schools and colleges.

We must give students opportunities to succeed throughout their time in the academic pipeline, not just when they are applying to college. College access starts with informing the public about the benefits and demands of adequate higher education preparation and it continues with implementing academic and social supports that help usher students through grade school and give them the experiences necessary to earning college admission on their own merits. We must raise expectations for students academically and personally. With raised expectations comes the need for increased academic and societal supports (e.g. structures to meet student needs, develop community partnerships, help students meet college requirements etc.) to help students reach those expectations. With efforts such as these, we are attempting to help students access college according to merit and not demographic factors.

In cases where hard-working underrepresented students are still having college access issues, an examination of all current higher educational opportunities should ensue to find a good fit. The higher education landscape has greatly expanded with the rise of for-profit colleges and open access policies; information and opportunities to earn academic credentials are more available than at any other time in history. Open access and nearly open access universities are accounting for the greatest gains in graduation rates at the lowest costs per student which challenges the notion that only highly selective colleges are likely to have higher rates of completion (Doyle, 2010). Students should consider all educational opportunities before applying for admission. Once students are admitted, it is important for colleges to provide tools for students to graduate; this may come in the form of financial support.

What if my suggestions still do not help minority students and students of lower socio-economic backgrounds gain access to higher education? At that point, colleges need to contemplate implementing affirmative action policies that consider class descriptors along with racial and gender indices.

There are significant arguments in favor of including social-class as one of the determinants of AA policies. One such argument is that with improved social awareness and better anti-discrimination laws, race has become less important relative to class. Thus, giving preferences based on class would do more to equalize opportunities (Timmons, 2009). Some argue that class is a better indicator of disadvantage and better promotes quality of opportunity. This argument is logical since racial minorities who come from upper-class socio-economic backgrounds are not likely to experience as many access obstacles as students of lower social standing regardless of their race. Additionally, class-based affirmative action is seen by many as a more thorough way to address past and present discrimination. Since racial minorities are more likely to hail from lower class brackets, class-based affirmative action helps create racial diversity. Many would argue that class cannot be used as a proxy for race, but the suggestion here is that both class and race descriptors should be considered in admissions decisions. Finally, class-based affirmative action would impose less of a stigma effect, because an individual's class is harder to identify than one's race or ethnicity (Timmons, 2009). Under this line of thinking, students admitted as a result of class-based AA would not be easily identifiable and thus would feel more like they belong and are not simply undeserving recipients of arbitrary race-based special treatment. 
Despite the potential benefits of using class-based indictors in higher education AA initiatives, it does not appear that colleges are doing enough to recruit students of lower socio-economic status. The number of students from lower class backgrounds enrolling in selective institutions is decreasing. A 2004 Century Foundation study found that at the most selective 146 institutions, 74 percent of students come from the richest socioeconomic quarter of the population, and just 3 percent from the bottom quarter, a roughly 25:1 ratio (The Chronicle Review, 2009). Not only do colleges need to recruit low-income students, they need to provide supports to prevent them from dropping out once enrolled. Students often drop out of college because they are not economically able to continue. A report by Edward Fiske found that a new program, the Carolina Covenant, has increased graduation rates by ensuring that financial aid and support programs are in place for low-income students (The Chronicle Review, 2009). Thus, class-based affirmative action can help increase graduation rates if sufficient post-enrollment support mechanisms are in place.

Race is only one aspect of diversity. Admitting students to colleges based on race alone does not guarantee that students of all races will be exposed to a wider variety of opinions and intellectual talent. Students of different races do not necessarily have different views than those of whites. This fact draws into question the ability of affirmative action policies to produce a truly diverse atmosphere on campus. As a society, we need to question the goal of affirmative action. If we are truly trying to make college campuses as reasonably diverse as possible, admitting students based on race alone will not accomplish that. Adding or prioritizing class as an AA admissions tool can greatly benefit students in less affluent states. With the current proliferation of alternative higher education opportunities offered by institutions such as for-profit colleges, students with different academic and career goals can reach their goals without attending traditional colleges where admission practices and standards are stricter. As a society, we must avoid a myopic focus on college admission and work on better preparing students to be admitted to college and succeed in college environments on their own academic merits. We need to raise our expectations for all students. This means that students should be armed with critical thinking, basic research, and problem solving skills before they submit their college applications. Better college preparation means that fewer students should need to take remedial courses once they are admitted. Basic literacy skills should be mastered by all students before college entrance. Higher education officials at all levels and sectors need to clearly articulate what is expected of students upon matriculation. Once admitted to college, colleges need to have strong supports in place to help students graduate in a reasonable time frame and gain skills necessary to compete in an increasingly global economy.

All students can benefit from college exposure. Affirmative action based on race is one way to help marginalized students gain access to college. Just as race is only one factor in creating diversity, admissions practices are only one factor in increasing college access for all Americans. If we are going to be a nation of AA, we need to realize that class-based admissions decisions, in combination with race-based admissions, can help create a higher level of potential social and intellectual diversity on campus than by simply using race alone. However, admissions preference practices are not the only or best ways to offset the disadvantages faced by minorities, historical or otherwise.

\section{CONCLUSION}

In conclusion, in its current form, affirmative action is more about diversity than fairness. It is not reasonable to deny an accomplished student access to college in favor of students with certain racial or socioeconomic backgrounds. This practice sends the negative message that hard academic work will not necessarily be rewarded come admissions time. We cannot fool ourselves by thinking AA, in its current form, is solving our country's racial problems. By simply admitting students based on social and racial indicators, we are missing the bigger picture. We need to investigate the functioning of our entire k-16 academic pipeline and accordingly fix issues related to academic preparedness and address deficiencies or omissions in structural support mechanisms that hinder students from both gaining access to higher education and completing their academic paths. What good are AA practices if the resulting admitted students do not have the basic skills necessary to fully make the most of their academic opportunities? Admissions committees cannot rectify what was not done from kindergarten through high school. Plainly stated, the k-12 system needs to do a better job of preparing students for college experiences, both academically and socially. This means that students should be made aware of all possible post-secondary educational opportunities from trade schools and for-profits to traditional national research universities, both public and private. Students should not be encouraged to view traditional non-profit colleges as the "best" or only options 
to reach their personal and career goals. Academically, k-12 schools need to help students meet their individual academic goals. This means schools must help students learn not only basic academic skills required for traditional colleges, but also gain insights into what will be required of them in non-traditional higher education settings. Better prepared students will be less likely to experience academic difficulties once they arrive at college. If we can definitively prove that AA action policies enhance the quality of higher education then class-based indicators should be utilized by admission committees in addition to racial indicators. Genuine educational diversity is both economic and cultural. However, if we, as a nation, make education, in general, and college access a priority starting early in the k-12 continuum, students will be better informed about their higher education options and will more likely possess the skills that are necessary to facilitate their admission based on academic merits. This would obviate the need for comprehensive affirmative action initiatives.

\section{AUTHOR INFORMATION}

Matthew R. Hodgman is a Ph.D. candidate in Educational Leadership and Policy at the College of Human Resources and Education at West Virginia University where he also holds the position of Graduate Research Assistant for Project DELTA. Previously, Mr. Hodgman served as an adjunct professor of general education at Westwood College and as an instructor at Chyten Educational Services. He holds degrees from Georgetown, Johns Hopkins, George Washington, and the University of Pennsylvania. E-mail: hodgman80@ hotmail.com

\section{REFERENCES}

1. College Board. (2005). Education Pays. Retrieved from http://www.collegeboard.com/prod_downloads/press/cost05/education_pays_05.pdf

2. Doyle, W.R. (2012, February). Open-access colleges responsible for greatest gains in graduation rates. The National Center for Public Policy and Higher Education. Retrieved from http://www.highereducation.org/pa_0210/index.shtml

3. Education Week. (2011, July 8) College Access. Retrieved from http://www.edweek.org/ew/issues/collegeaccess/

4. Hoover, E. (2011, May 15). College's value goes deeper than the degree graduates say. Chronicle of Higher Education. Retrieved from http://chronicle.com/article/Its-More-Than-Just-the/127534/

5. Leonhardt, D. (2007, September 30). The new affirmative action. The New York Times. Retrieved from http://www.nytimes.com/2007/09/30/magazine/30affirmative-t.html?pagewanted=all

6. Schmidt, P. (2012, January 4). New Hampshire ends affirmative-action preferences at colleges. Chronicle of Higher Education. Retrieved from http://chronicle.com/article/New-Hampshire-Ends/130196/

7. The Chronicle Review. (2009, December 16). Reactions: Is it time for class-based affirmative action? Chronicle of Higher Education. Retrieved from http://chronicle.com/article/Reactions-is-it-Timefor/62615/

8. Timmons, G. (2009, April). Affirmative action: Race, class or none of the above. PBS Online. Retrieved from http://webcache.googleusercontent.com/search?q=cache:583abLhy NAJ:www.pbs.org/newshour/extra/teac hers/lessonplans/us/janjune09/affirmative action.html+consider+social+class+in+affirmative+action\&cd=1\&hl=en\&ct=clnk\&gl= us\&client=firefox-a 
NOTES 